\title{
PEMENUHAN HAK MENYAMPAIKAN KELUHAN BAGI ANAK DI LEMBAGA PEMASYARAKATAN ANAK BLITAR
}

\author{
Bagus Bayu Prabowo
}

Setda Kabupaten Malang

Jl. Panji 178 Kepanjen Kabupaten Malang

Email: bagusbayuprabowo@yahoo.com

\begin{abstract}
This scientific article discuss the fulfilment of the rights lodge complaints for Children in a correctional institution the son of Blitar, associated with the principle of child protection that was found in the Act of number 11/2012 about Criminal Justice Systems Child.The problems raised by the writer, on the implementation of fulfilling the right lodge complaints for children in a correctional institution the son of Blitar that reflects the principle of child protection. Was continued by knowing obstacles and the efforts made by a correctional institution in the son of blitar fulfilling the right lodge complaints for children in a correctional institution the son of Blitar. Empirical research is kind of the prevailing approach to yuridicial sociological. Of the results of research we can see that the implementation of the right lodge complaints to the correctional institution in the blitar have been reflecting the principle of child protection contained in the Act of number 11/2012 about Criminal Justice Systems Children. The principles of child protection in the implementation of development of the main coaching against children who undergo criminal in a correctional institution children are: the principle of protection, the principle of non discrimination, the principle of the best interests for children, the principle of the right of life, grow and flourish, the principle of training and coaching, the principle of proportionate. In terms of nurturing a right to complain of the correctional institution for the protection of children (made of cement the principles of refuge in principle, against the best interests of the child, the principle of life grow and develop, the principle of development and coaching, the principle of proportional) has done or accomplished.For the fulfillment of the rights of the child in his complaint made of cement a correctional institution and there are few obstacles to or derived from the correctional officers to undergo a criminal himself.
\end{abstract}

Key words: complaint, children, protection of children

\begin{abstract}
Abstrak
Artikel ilmiah ini membahas tentang Pemenuhan Hak Menyampaikan Keluhan Bagi Anak di Lembaga Pemasyarakatan Anak Blitar, dikaitkan dengan Prinsip Perlindungan Anak yang terdapat dalam Undang-Undang Nomor 11 Tahun 2012 tentang Sistem Peradilan Pidana Anak. Permasalahan yang diangkat oleh penulis, mengenai pelaksanaan pemenuhan hak menyampaikan keluhan bagi anak di Lembaga Pemasyarakatan Anak Blitar yang mencerminkan prinsip perlindungan anak. Kemudian dilanjutkan dengan mengetahui kendala dan upaya yang dilakukan oleh Lembaga Pemasyarakatan Anak Blitar dalam pemenuhan hak menyampaikan keluhan bagi anak di Lembaga Pemasyarakatan Anak Blitar. Jenis penelitian adalah penelitian empiris dengan metode pendekatan yuridis sosiologis. Dari hasil penelitian yang dilakukan maka dapat diketahui bahwa pelaksanaan hak menyampaikan keluhan bagi anak di Lembaga Pemasyarakatan Anak Blitar telah mencerminkan prinsip perlindungan anak yang terdapat
\end{abstract}


dalam Undang-undang Nomor 11 Tahun 2012 tentang Sistem Peradilan Pidana Anak. PrinsipPrinsip perlindungan anak dalam pelaksanaan pembinaan utamanya pembinaan terhadap anak yang menjalani pidana pada Lembaga Pemasyarakatan Anak diantaranya: prinsip perlindungan, prinsip non diskriminasi, prinsip kepentingan terbaik bagi anak, prinsip hak hidup, tumbuh dan berkembang, prinsip pembinaan dan pembimbingan, prinsip proporsional. Dalam pelaksanaan pembinaan utamanya pemenuhan hak menyampaikan keluhan bagi anak pada Lembaga Pemasyarakatan Anak Blitar keenam prinsip-prinsip perlindungan anak (prinsip perlindungan, prinsip non diskriminasi, prinsip kepentingan terbaik bagi anak, prinsip hak hidup, tumbuh dan berkembang, prinsip pembinaan dan pembimbingan, prinsip proporsional) telah dilaksanakan dan /atau terpenuhi. Pelaksanaan pemenuhan hak menyampaikan keluhan bagi anak pada Lembaga Pemasyarakatan Anak Blitar terdapat beberapa kendala dan upaya yang berasal petugas pemasyarakatan maupun dari anak yang menjalani pidana sendiri.

Kata kunci: keluhan, anak, perlindungan anak

\section{Latar Belakang}

Sistem Peradilan Pidana merupakan suatu sistem penegakan hukum sebagai upaya penanggulangan kejahatan. ${ }^{1}$ Sistem Peradilan Pidana terdiri dari 4 (empat) bagian, yaitu Kepolisian dalam melakukan penyelidikan dan penyidikan, Kejaksaan dalam melakukan penuntutan, Pengadilan dalam melakukan pemeriksaan dalam persidangan dan Lembaga Pemasyarakatan dalam melakukan pembinaan. $^{2}$

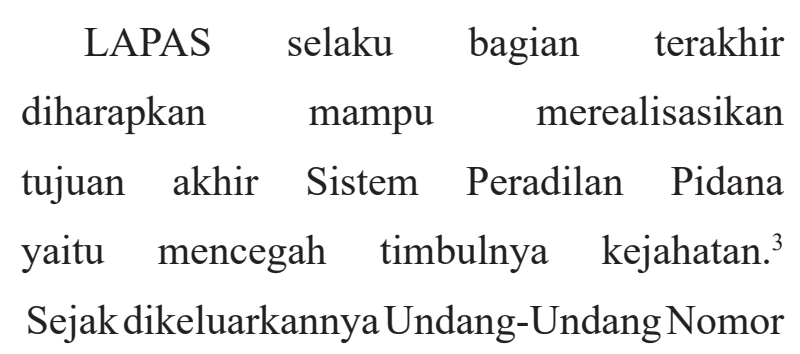

12 Tahun 1995 tentang Pemasyarakatan, Lembaga Pemasyarakatan merupakan salah satu bagian akhir dari Sistem Peradilan Pidana terpadu (Integreted Criminal Justice System) dimana sasaran akhir dari Lembaga Pemasyarakatan adalah mengembalikan Warga Binaan Pemasyarakatan sebagai warga yang baik dan meminimalisir pengulangan perbuatan pidana yang dilakukan oleh Warga Binaan Pemasyarakatan. ${ }^{4}$

Anak merupakan generasi penerus bangsa, oleh karena itu diperlukan adanya bimbingan khusus yang dimulai dari aspek terkecil dalam kehidupan yaitu keluarga, masyarakat maupun negara sehingga tumbuh kembang anak dapat berjalan sesuai dengan apa yang diharapkan. ${ }^{5}$

1 Romli Atmasasmita, Sistem Peradilan Pidana, Bina Cipta, Jakarta, 1996, hlm. 26.

2 Ibid., hlm. 29.

3 Petrus Iwan Panjaitan dan Pandapotan Simorangkir, Lembaga Pemasyarakatan dalam Perspektif Peradilan Pidana, Pustaka Sinar Harapan, Jakarta, 1995, hlm. 75.

4 Penjelasan Umum Undang-undang Nomor 12 Tahun 1995 tentang Pemasyarakatan.

5 R. Soeroso, Pengantar IImu Hukum, Sinar Grafika, Jakarta, 2009, hlm. 97. 
Dalam konstitusi Indonesia, anak memiliki peran signifikan yang dijelaskan bahwa negara Indonesia mengakui hak anak untuk hidup, tumbuh dan berkembang serta atas perlindungan dari kekerasan dan diskriminasi. ${ }^{6}$

Dalam melaksanakan aktifitas kehidupan sehari-hari yang ada dalam masyarakat anak memiliki hak yang sangat hakiki, diantaranya: ${ }^{7}$

a. Anak berhak untuk dapat hidup, tumbuh, berkembang;

b. Anak berhak atas suatu nama sebagai identitas diri dan status kewarganegaraan;

c. Anak berhak untuk melaksanakan ibadah sesuai dengan agama dan kepercayaannya;

d. Anak berhak untuk mengetahui orang tuanya;

e. Anak berhak untuk memperoleh pelayanan kesehatan;

f. Anak berhak untuk memperoleh pendidikan dan pengajaran;

g. Anak berhak untuk menyatakan pendapat dan didengar pendapatnya;

h. Anak berhak untuk beristirahat dan memanfaatkan waktu luang.

Perkara pidana yang dilakukan oleh anak perlu diselesaikan melalui suatu lembaga peradilan khusus yaitu peradilan anak dengan menggunakan hukum pidana anak beserta hukum acara pidananya. ${ }^{8}$
Selain itu juga diperlukan pertimbangan hukum atau pertimbangan-pertimbangan lain sebelum hakim menjatuhkan putusan, karena putusan hakim akan mempenggaruhi kehidupan selanjutnya dari anak yang bersangkutan. ${ }^{9}$

Tujuan penjatuhan pidana bagi anak bukan ditujukan untuk memberikan hukuman atau penderitaan bagi anak atas perbuatan yang telah dilakukannya akan tetapi diarahkan pada pembinaan dan pendidikan yang diperlukan bagi perkembangan jiwanya serta dimaksudkan untuk memberikan kesempatan pada anak agar melalui pembinaan diperoleh jati dirinya untuk menjadi manusia yang mandiri, bertanggung jawab dan berguna bagi dirinya, keluarga, masyarakat, bangsa dan negara. ${ }^{10}$

Anak yang berhadapan dengan hukum bukan merupakan suatu hasil dari berbagai fenomena kompleks yang terjadi di masyarakat. Baik sebagai korban maupun pelaku, anak yang berhadapan dengan hukum bagaimanapun juga masih merupakan anak yang memerlukan bantuan, karena sifatnya yang masih bergantung serta dalam masa pertumbuhan dan perkembangan. ${ }^{11}$

6 Penjelasan Umum Undang-undang Nomor 11 Tahun 2012 tentang Sistem Peradilan Pidana Anak.

7 Undang-undang Nomor 23 Tahun 2002 tentang Perlindungan Anak, sebagaimana telah diubah dengan Undang-undang Nomor 35 Tahun 2014 tentang Perubahan atas Undang-undang Nomor 23 Tahun 2002 tentang Perlindungan Anak.

8 Maidin Gultom, Perlindungan Hukum terhadap Anak dalam Sistem Peradilan Pidana Anak di Indonesia, Refika Aditama, Bandung, 2008, hlm. 101.

9 Lilik Mulyadi, SH.MH, Pengadilan Anak di Indonesia, Teori, Praktik dan Permasalahannya, Mandar Maju, Bandung, 2005, hlm. 67.

10 Darwan, Hukum Anak Indonesia, Citra Aditya Bakti, Bandung, 2003, hlm. 31.

11 Anak yang berkonflik dengan hukum, http//dirjenpemasyarakatan.go.id, diakses 10 Februari 2015 pukul 10.00 WIB. 
Dalam pandangan hak asasi anak, khususnya Anak yang Berhadapan dengan Hukum masih harus terus diperhatikan. ${ }^{12}$

Meskipun anak berdasarkan putusan pengadilan dinyatakan bersalah dan ditempatkan dalam penjara, anak tetap harus mendapatkan perlindungan. Berdasarkan Konvensi Hak Anak, terdapat 4 (empat) prinsip perlindungan anak yang menjadi dasar bagi setiap negara dalam menyelenggarakan perlindungan anak, diantaranya: ${ }^{13}$

1. Prinsip Non Diskriminasi.

2. Prinsip Kepentingan Terbaik Bagi Anak (Best Interest of The Child).

3. Prinsip Hak Hidup, Kelangsungan Hidup dan Perkembangan (Right to Life, Survival and Development).

4. Prinsip Penghargaan terhadap Pendapat Anak (Respect for the views of the Child).

Perlindungan hukum bagi anak dapat diartikan sebagai upaya perlindungan hukum terhadap berbagai kebebasan dan hak asasi anak (fundamental right and freedoms of children) serta berbagai kepentingan yang berhubungan dengan kesejahteraan anak. ${ }^{14}$ Berangkat dari pembatasan tersebut, maka perlindungan hukum bagi anak mencakup: ${ }^{15}$

1. Perlindungan terhadap kebebasan anak;

2. Perlindungan terhadap hak asasi anak;

3. Perlindungan terhadap semua kepentingan anak yang berkaitan dengan kesejahteraan.
Pemerintah Indonesia sebagai pihak dalam Konvensi Hak Anak yang mengatur prinsip perlindungan hukum terhadap anak mempunyai kewajiban untuk memberikan perlindungan khusus terhadap anak yang berhadapan dengan hukum, yaitu dengan mengeluarkan "Undang-Undang Nomor 39/1999 tentang Hak Asasi Manusia, UndangUndang Nomor 23/2002 tentang Perlindungan Anak sebagaimana telah diubah dengan UndangUndang Nomor 35/2014 tentang Perubahan atas Undang-Undang Nomor 23/2002 dan UndangUndang Nomor 11/2012 tentang Sistem Peradilan Pidana Anak".

Pemerintah telah melakukan usaha perlindungan anak yaitu dengan diterbitkannya UU 11 Tahun 2012 tentang SPPA. Namun dalam pelaksanaannya masih banyak terdapat kendala untuk dapat melaksanakannya secara sempurna sesuai dengan amanat Konvensi Hak Anak. Untuk itu Anak yang Berhadapan dengan Hukum perlu penanganan berbeda dibandingkan dengan orang dewasa. Oleh karena itu Lembaga Pembinaan Khusus Anak harus dapat memberikan dukungan yang layak bagi perlindungan Anak yang Berhadapan dengan Hukum.

12 Priyatno, Dwidja, Pelaksanaan Pidana Penjara di Indonesia, Refika Aditama, Bandung, 2002, hlm. 45.

13 Hadi Supeno, Kriminalisasi Anak Tawaran Gagasan Radikal Peradilan Anak tanpa Pemidanaan, Gramedia Pustaka Utama, Jakarta, 2010, hlm. 53.

14 Barda Nawawi Arief, Beberapa Aspek Kebijaksanaan Penegakan dan Pengembangan Hukum Pidana, Citra Aditya Bakti, Bandung, 1998, hlm. 153.

15 Pasal 1 angka 2 Undang-undang Nomor 23 Tahun 2002 tentang Perlindungan Anak.

"Perlindungan anak adalah segala kegiatan untuk menjamin dan melindungi anak dan hak-haknya agar dapat hidup, tumbuh, berkembang, berpartisipasi secara optimal sesuai dengan harkat dan martabat kemanusiaan serta mendapat perlindungan dari kekerasan dan diskriminasi" 
Berdasarkan ketentuan pada UU No 11 Tahun 2012 tentang SPPA, Anak yang menjalani pidana ditempatkan di Lembaga Pembinaan Khusus Anak. Anak yang sedang menjalani pidana di dalam Lembaga Pembinaan Khusus Anak memiliki hak ${ }^{16}$, diantaranya:
a. Anak yang menjalani pidana mendapat pengurangan masa pidana;
b. Anak yang menjalani pidana memperoleh asimiliasi;
c. Anak yang menjalani pidana memperoleh cuti mengunjungi keluarga;
d. Anak yang menjalani pidana memperoleh pembebasan bersyarat;
e. Anak yang menjalani pidana memperoleh cuti menjelang bebas;
f. Anak yang menjalani pidana memperoleh cuti bersyarat;
g. Anak yang menjalani pidana memperoleh hak-hak lain sesuai dengan ketentuan peraturan perundang-undangan.

Anak yang menjalani pidana di Lembaga Pemasyarakatan Anak Blitar mempunyai hak menyampaikan keluhan yang diperolehnya selama menjalani masa pidananya. ${ }^{17}$

Ketentuan mengenai mekanisme pengaturan hak menyampaikan keluhan yang dimiliki oleh anak di Lembaga Pemasyarakatan Anak diatur dalam PP 32/1999 tentang Syarat dan Tata Cara Pelaksanaan Hak Warga Binaan Pemasyarakatan.

Lembaga Pemasyarakatan Anak sebagai tempat anak menjalani masa pidananya, tidak serta merta dapat merealisasikan semua keluhan yang disampaikan oleh anak.
Keluhan yang disampaikan oleh anak haruslah disesuaikan dengan kondisi riil pada diri anak yang dapat diketahui dalam pelaksanaan Sidang Tim Pengamat Pemasyarakatan (TPP). Lembaga Pemasyarakatan Anak merupakan tempat menampung, membina dan merehabilitasi anak yang menjalani hukuman pidana. Diharapkan Lembaga Pemasyarakatan Anak melalui kegiatan pembinaan dapat meningkatkan kualitas anak sehingga anak menyadari kesalahannya dan tidak mengulanggi perbuatan pidana yang pernah dilakukannya.

Anak yang ditempatkan di Lembaga Pemasyarakatan Anak memerlukan perhatian, bantuan dari semua pihak terkait. Hal ini dikarenakan anak belum memungkinkan untuk mandiri. Mereka masih bergantung pada lingkungan sekitar ataupun pihak lain guna menunjang kehidupannya. Dalam meningkatkan perkembangan anak pada khususnya, anak yang menjalani pidana di Lembaga Pemasyarakatan Anak bukan hanya tanggung jawab dari petugas kemasyarakatan atau Kementerian Hukum dan HAM saja, akan tetapi diperlukan adanya kerjasama antara pihak-pihak terkait dalam pelaksanaan pembinaan.

Sehingga menjadi sebuah ketertarikan bagi penulis untuk menganalisanya dalam tulisan ini dengan judul PEMENUHAN HAK MENYAMPAIKAN KELUHAN 
BAGI ANAK DI LEMBAGA penulis dengan alasan untuk mengetahui

\section{PEMASYARAKATAN}

YANG MENCERMINKAN PRINSIP PERLINDUNGAN ANAK (Studi di

Lembaga Pemasyarakatan Anak Blitar).

Judul tersebut mencakup rumusan masalah pertama yang hendak dianalisis oleh penulis yaitu apakah pelaksanaan pemenuhan hak menyampaikan keluhan bagi anak di Lembaga Pemasyarakatan Anak Blitar telah mencerminkan prinsip perlindungan anak. Kemudian dilanjutkan pada rumusan masalah kedua yaitu penulis menganalisa tentang kendala dan upaya apakah yang dihadapi oleh Lembaga Pemasyarakatan Anak Blitar dalam pemenuhan hak menyampaikan keluhan bagi anak di Lembaga Pemasyarakatan Anak Blitar.

Penganalisaan rumusan permasalahan tersebut, penulis menggunakan metode penelitian berjenis empiris, kemudian menggunakan pendekatan yuridis sosiologis dalam penyusunan pembahasan guna mencapai hasil analisa berdasar dari rumusan masalah yang diangkat.

Pendekatan yuridis sosiologis menjadi pilihan penulis dalam menyusun pembahasan karena pendekatan ini mengarahkan penulis untuk mengetahui kondisi riil yang terdapat pada Lembaga Pemasyarakatan Anak Blitar utamanya dalam hal pelaksanaan pemenuhan hak menyampaikan keluhan bagi anak yang menjalani pidana. Kemudian pendekatan perundang-undangan juga menjadi pilihan dasar hukum dalam pelaksanaan pemenuhan hak menyampaikan keluhan bagi anak yang menjalani pidana di Lembaga Pemasyarakatan Anak, sehingga dapat diketahui apakah aturan yang telah ada sesuai dengan pelaksanaan yang terdapat di lapangan (Lembaga Pemasyarakatan Anak).

Data yang digunakan dalam jurnal ini adalah data primer dan data sekunder. Data primer diperoleh dengan menanyakan secara langsung kepada Petugas Pemasyarakatan yang terdapat pada Seksi Bimbingan Anak Didik serta beberapa anak yang menjalani pidana pada Lembaga Pemasyarakatan Anak Blitar. Data sekunder diperoleh dari dokumendokumen, hasil penelitian dan peraturan perundang-undangan (Konvensi Hak Anak, Undang-Undang Nomor 12 tahun 1995 tentang Pemasyarakatan, Undang-Undang Nomor 11 tahun 2012 tentang Sistem Peradilan Pidana Anak, Peraturan Pemerintah Nomor 31 tahun 1999 tentang Pembinaan dan Pembimbingan Warga Binaan Pemasyarakatan, Peraturan Pemerintah Nomor $\quad 32$ tahun 1999 tentang Syarat Dan Tata Cara Pelaksanaan Hak Warga Binaan Pemasyarakatan. Kemudian berbagai aturan yang mengikuti akan dianalisa dengan menggunakan salah satu teknik analisa yaitu deskriptif analisis yaitu data yang diperoleh akan dianalisis dan digambarkan sedemikian rupa sehingga ditarik suatu kesimpulan. 


\section{Pembahasan}

\section{A. Gambaran Umum Lokasi Penelitian}

Lembaga Pemasyarakatan Anak Blitar merupakan Lembaga Pemasyarakatan Anak satu-satunya yang terdapat pada provinsi Jawa Timur. Lembaga Pemasyarakatan Anak berfungsi sebagai tempat menampung, membina dan merehabilitasi anak yang menjalani hukuman pidana. Diharapkan melalui kegiatan pembinaan, dapat meningkatkan kualitas anak sehingga menyadari kesalahannya dan tidak mengulanggi pelanggaran yang telah dilakukannya. Penelitian dilakukan di Seksi Bimbingan Anak Didik pada Lembaga Pemasyarakatan Anak Blitar. Seksi Bimbingan Anak Didik pada Lembaga Pemasyarakatan Anak Blitar mempunyai tugas memberikan bimbingan pemasyarakatan pada Anak Didik Pemasyarakatan (Anak Pidana).

\section{Bagan 1. Struktur Organisasi Lembaga Pemasyarakatan Anak Blitar}

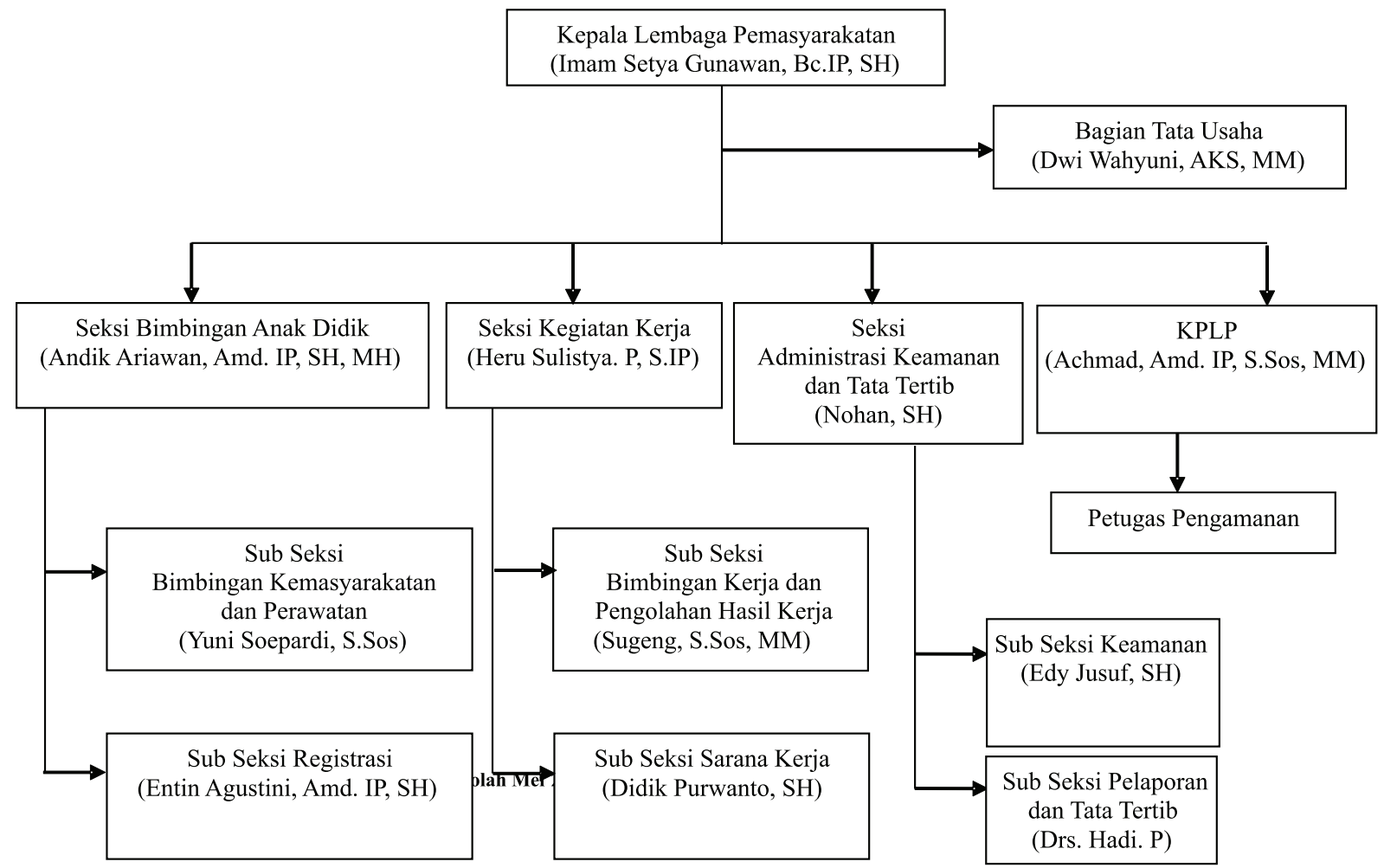

Sumber: Data Sekunder (diolah Mei 2015)

Lembaga Pemasyarakatan Anak terdiri dari: Seksi Bimbingan Anak Didik, Blitar dipimpin oleh Kepala Lembaga Seksi Bimbingan Kerja, Seksi Administrasi Pemasyarakatan yang dibantu oleh Bagian Keamanan dan Tata Tertib dan KPLP. 


\section{Sarana dan prasarana lembaga pemasyarakatan anak Blitar}

Dalam rangka kelancaran dan ketertiban dalam pelaksanaan pembinaan terhadap Anak Didik Pemasyarakatan (Anak Pidana) dan supaya tujuan dari pembinaan dapat tercapai diperlukan sarana-sarana fisik maupun non fisik.

Pada Lembaga Pemasyarakatan Anak Blitar terdapat 31 (tiga puluh satu) kamar tahanan bagi Anak Didik Pemasyarakatan (Anak Pidana) yang dibagi menjadi 5 (lima) blok, yaitu: wisma anggrek, wisma bogenvil, wisma cepaka, wisma dahlia dan wisma melati.
Pada Lembaga Pemasyarakatan Anak Blitar terdapat sarana dan prasarana dalam rangka pelaksanaan pembinaan terhadap Anak Didik Pemasyarakatan (Anak Pidana), yaitu: masjid, klinik kesehatan, perpustakaan, ruang kelas dan ruang ketrampilan.

\section{Pegawai lembaga pemasyarakatan anak Blitar}

Jumlah pegawai yang terdapat di Lembaga Pemasyarakatan Anak Blitar berjumlah 55 (lima puluh lima) orang pegawai (pegawai laki-laki berjumlah 45 (empat puluh lima) orang dan pegawai perempuan berjumlah 10 (sepuluh) orang) ${ }^{18}$, sebagaimana tercantum dalam tabel di bawah ini.

Tabel 1. Jumlah Pegawai Lembaga Pemasyarakatan Anak Blitar (Bulan Mei 2015)

\begin{tabular}{|c|c|c|c|c|}
\hline NO. & $\begin{array}{l}\text { PEGAWAI } \\
\text { (Bagian) }\end{array}$ & $\begin{array}{l}\text { LAKI- } \\
\text { LAKI } \\
\text { (Orang) }\end{array}$ & $\begin{array}{l}\text { PEREM- } \\
\text { PUAN } \\
\text { (Orang) }\end{array}$ & JUMLAH \\
\hline 1 & 2 & 3 & 4 & 5 \\
\hline 1 & $\begin{array}{l}\text { Tata Usaha } \\
\text { - Umum } \\
\text { - Kepegawaian dan Keuangan }\end{array}$ & $\begin{array}{l}3 \\
2\end{array}$ & $\begin{array}{l}1 \\
1 \\
3\end{array}$ & $\begin{array}{l}1 \\
4 \\
5\end{array}$ \\
\hline 2 & $\begin{array}{l}\text { Bimbingan Anak Didik } \\
\text { - Registrasi } \\
\text { - Bimbingan Kemasyarakatan dan } \\
\text { Perawatan }\end{array}$ & $\begin{array}{l}1 \\
1 \\
5\end{array}$ & $\begin{array}{l}2 \\
2\end{array}$ & $\begin{array}{l}1 \\
3 \\
7\end{array}$ \\
\hline 3 & $\begin{array}{l}\text { Kegiatan Kerja } \\
\text { - Bimbingan Kerja dan Pengolahan Hasil } \\
\text { Kerja } \\
\text { - Sarana Kerja }\end{array}$ & $\begin{array}{l}1 \\
2 \\
1\end{array}$ & $\begin{array}{l}1 \\
-\end{array}$ & $\begin{array}{l}1 \\
3 \\
1\end{array}$ \\
\hline 4 & $\begin{array}{l}\text { Administrasi Keamanan dan Tata Tertib } \\
\text { - Keamanan } \\
\text { - Pelaporan dan Tata Tertib }\end{array}$ & $\begin{array}{l}1 \\
1 \\
1\end{array}$ & - & $\begin{array}{l}1 \\
1 \\
1\end{array}$ \\
\hline 5 & $\begin{array}{l}\text { Kesatuan Pengamanan Lembaga } \\
\text { Pemasyarakatan }\end{array}$ & 25 & - & 25 \\
\hline JUMLAH & & 45 & 10 & 55 \\
\hline
\end{tabular}

\section{Sumber: Data Sekunder (diolah Mei 2015)}

18 Wawancara dengan Rudy Christanto, SH, MH, Kepala Urusan Kepegawaian dan Keuangan pada Lembaga Pemasyarakatan Anak Blitar, 7 Mei 2015. 
3. Penghuni lembaga pemasyarakatan anak Blitar

Jumlah penghuni Lembaga

Pemasyarakatan Anak Blitar berjumlah
123 (seratus dua puluh tiga) orang, yang terdiri dari Anak Didik Pemasyarakatan (Anak Pidana) berjumlah 118 (seratus delapan belas) orang dan Tahan berjumlah 5 (lima) orang. ${ }^{19}$

Tabel 3. Jumlah Penghuni di Lembaga Pemasyarakatan Anak Blitar (Bulan Mei 2015)

\begin{tabular}{|c|c|c|c|c|c|c|c|}
\hline NO & USIA & \multicolumn{2}{|c|}{ ANAK DIDIK } & \multicolumn{3}{|c|}{ TAHANAN } & JUMLAH \\
\hline & & B I & B II & A I & A II & A III & \\
\hline $\mathbf{1}$ & $\mathbf{2}$ & $\mathbf{3}$ & $\mathbf{4}$ & $\mathbf{5}$ & $\mathbf{6}$ & $\mathbf{7}$ & $\mathbf{8}$ \\
\hline 1 & $<15$ Tahun & - & - & - & - & - & - \\
\hline 2 & $15-18$ Tahun & 66 & 10 & 3 & - & 2 & 81 \\
\hline 3 & $>18$ Tahun & 42 & - & - & - & - & 42 \\
\hline \multicolumn{2}{|c|}{ JUMLAH } & $\mathbf{1 0 8}$ & $\mathbf{1 0}$ & $\mathbf{3}$ & - & $\mathbf{2}$ & $\mathbf{1 2 3}$ \\
\hline
\end{tabular}

Sumber: Data Sekunder (diolah Mei 2015)

B. Pelaksanaan Pemenuhan Hak Pemasyarakatan(Anak Pidana) pada Lembaga Menyampaikan Keluhan Bagi Pemasyarakatan Anak Blitar dibutuhkan/ Anak Didik Pemasyarakatan diperlukan adanya sistem perwalian. Wali (Anak Pidana) di Lembaga Pemasyarakatan berfungsi sebagai orang Pemasyarakatan Anak Blitar tua angkat bagi Anak Didik Pemasyarakatan Berdasarkan Prinsip Perlindungan (Anak Pidana) selama masa pembinaan.

Anak

1. Pelaksanaan pemenuhan hak menyampaikan keluhan bagi anak didik pemasyarakatan (anak pidana) di lembaga pemasyarakatan anak blitar

a. Wali pemasyarakatan sebagai penunjang Tim Pengamat Pemasyarakatan (TPP)

Dalam rangka optimalisasi pelaksanaan pembinaan terhadap Anak Didik
Adanya sistem perwalian didalam Lembaga Pemasyarakatan Anak Blitar diharapkan dapat menciptakan hubungan yang erat diantara Anak Didik Pemasyarakatan (Anak Pidana) dengan petugas yang ditunjuk sebagai wali pemasyarakatan sehingga akan diperoleh/digali informasi-informasi yang penting dan data-data yang penting dalam rangka pelaksanaan pembinaan.

\section{b. Proses penyampaian keluhan}

Anak Didik Pemasyarakatan (Anak Pidana) pada Lembaga Pemasyarakatan

19 Wawancara dengan Entin Agustini, Amd.IP, SH, Kepala Sub Seksi Registrasi pada Seksi Bimbingan Anak Didik Lembaga Pemasyarakatan Anak Blitar, 8 Mei 2015. 
Anak Blitar sesuai dengan ketentuan peraturan perundang-undangan memiliki hak dalam melaksanakan aktifitasnya. Salah satu hak yang dimiliki oleh Anak Didik Pemasyarakatan (Anak Pidana) di Lembaga Pemasyarakatan adalah hak menyampaikan keluhan. Keluh kesah yang dimiliki oleh Anak Didik Pemasyarakatan (Anak Pidana) dapat disampaikan secara lisan ataupun tertulis kepada Wali Pemasyarakatan. ${ }^{20}$

Setelah anak menyampaikan keluhan kepada Wali Pemasyarakatan dan menurut Wali Pemasyarakatan keluhan tersebut benar adanya (sesuai dengan kondisi riil yang ada) maka Wali Pemasyarakatan mengajukan ke dalam sidang tim pengamat pemasyarakatan. Selanjutnya dilakukan persidangan oleh tim pengamat kemasyarakatan yang terdiri dari beberapa seksi yang terdapat di dalam Lembaga Pemasyarakatan. Dalam persidangan tim pengamat pemasyarakatan bertujuan untuk memperoleh keputusan dari tim pengamat kemasyarakatan. Apakah keluhan yang disampaiakan tersebut diterima ataukah ditolak. Setiap seksi yang menjadi aggota persidangan memberikan rekomendasi berdasarkan penelitian kemasyarakatan yang sudah dilakukan.

Dalam hal keluhan yang disampaikan dalam sidang tim pengamat kemasyarakatan disetujui oleh lebih dari setengah anggota persidangan berdasarkan hasil penelitian pemasyarakatan yang dilakukan oleh masingmasing seksi maka keluhan yang disampaiakan oleh anak tersebut akan disetujuai dalam sidang tim pengamat pemasyarakatan. Hasil sidang tim pengamat kemasyarakatan diserahkan kepada Kepala Lembaga Pemasyarakatan untuk mendapatkan penetapan.

\section{c. Pelaksanaan sidang TPP}

Pelaksanaan sidang tim pengamat pemasyarakatan dihadiri oleh Ketua, Sekretaris, Anggota dan Wali Pemasyarakatan. Sidang dianggap sah apabila dihadiri oleh $2 / 3$ anggota sidang. ${ }^{21}$ Sidang membahas tentang keluhan yang disampaiakan oleh Anak Didik Pemasyarakatan (Anak Pidana) di dalam lembaga. Untuk dapat dikabulkan atau tidak dikabulkan keluhan yang telah disampaikan terlebih dahulu melihat laporan dari masingmasing anggota sidang terkait dengan penelitian dan pencatatan yang dilakukan oleh masing-masing seksi dalam rangka pelaksanaan pembinaan pada Anak Didik Pemasyarakatan (Anak Pidana).

Keputusan sidang dianggap sah apabila lebih dari separuh anggota sidang setuju atau menolak dengan dasar laporan pemasyarakatan yang telah dilakukannya.

\section{d. Jumlah Wali Pemasyarakatan}

Jumlah Wali Pemasyarakatan yang terdapat pada Lembaga Pemasyarakatan Anak Blitar berjumlah 23 (dua puluh tiga) orang

20 Wawancara dengan Yuni Soepardi, S.Sos, Wali Pemasyarakatan pada Lembaga Pemasyarakatan Anak Blitar, 8 Mei 2015.

21 Wawancara dengan Andik Ariawan, Amd.IP, SH, MH, Kepala Seksi Bimbingan Anak Didik pada Lembaga Pemasyarakatan Anak Blitar, 11 Mei 2015. 
pegawai (Wali Pemasyarakatan laki-laki dan Wali Pemasyarakatan perempuan berjumlah 18 (delapan belas) orang pegawai berjumlah 5 (lima) orang pegawai). ${ }^{22}$

Tabel 3. Jumlah Wali Pemasyarakatan di Lembaga Pemasyarakatan Anak Blitar (Bulan Mei 2015)

\begin{tabular}{|c|c|c|c|c|}
\hline NO & $\begin{array}{l}\text { PEGAWAI } \\
\text { (Bagian) }\end{array}$ & $\begin{array}{l}\text { LAKI-LAKI } \\
\text { (Orang) }\end{array}$ & $\begin{array}{c}\text { PEREM- } \\
\text { PUAN } \\
\text { (Orang) }\end{array}$ & JUMLAH \\
\hline 1 & 2 & 3 & 4 & 5 \\
\hline 1 & $\begin{array}{l}\text { Bimbingan Anak Didik } \\
\text { - Registrasi } \\
\text { - Bimbingan Kemasyarakatan dan } \\
\text { Perawatan }\end{array}$ & $\begin{array}{l}1 \\
1 \\
3\end{array}$ & $\begin{array}{l}- \\
2 \\
2\end{array}$ & $\begin{array}{l}1 \\
3 \\
5\end{array}$ \\
\hline 2 & $\begin{array}{l}\text { Kegiatan Kerja } \\
\text { - Bimbingan Kerja dan Pengolahan } \\
\text { Hasil Kerja } \\
\text { - Sarana Kerja }\end{array}$ & $\begin{array}{l}1 \\
2 \\
1\end{array}$ & $\begin{array}{l}- \\
1 \\
-\end{array}$ & $\begin{array}{l}1 \\
3 \\
1\end{array}$ \\
\hline 3 & $\begin{array}{l}\text { Administrasi Keamanan dan Tata } \\
\text { Tertib } \\
\text { - Keamanan } \\
\text { - Pelaporan dan Tata Tertib }\end{array}$ & $\begin{array}{l}1 \\
1 \\
1\end{array}$ & $\begin{array}{l}- \\
- \\
-\end{array}$ & $\begin{array}{l}1 \\
1 \\
1\end{array}$ \\
\hline 4 & $\begin{array}{l}\text { Kesatuan Pengamanan Lembaga } \\
\text { Pemasyarakatan }\end{array}$ & 6 & - & 6 \\
\hline JUMLAH & & 18 & 5 & 23 \\
\hline
\end{tabular}

\section{Sumber: Data Sekunder (diolah Mei 2015)}

\section{e. Bentuk keluhan anak didik pemasyarakatan (anak pidana)}

Anak Didik Pemasyarakatan (Anak Pidana) dalam melaksanakan aktifitasnya pada Lembaga Pemasyarakatan Anak Blitar memiliki hak untuk menyampaikan keluhan. ${ }^{23}$ Keluhan yang dimiliki oleh Anak Didik Pemasyarakatan (Anak Pidana) dapat disampaikan secara tertulis atau lisan kepada Wali Pemasyarakatan.
Bentuk-bentuk keluhan yang disampaikan oleh Anak Didik Pemasyarakatan (Anak Pidana) pada Lembaga Pemasyarakatan Anak Blitar kepada Wali Pemasyarakatan, diantaranya:

a) Anak Didik Pemasyarakatan (Anak Pidana) mengeluhkan jarang dikunjungi oleh keluarganya.

b) Anak Didik Pemasyarakatan (Anak Pidana) mengeluhkan ingin memperoleh

22 Wawancara dengan Yuni Soepardi, S.Sos, Kepala Sub Seksi Bimbingan Kemasyarakatan dan Perawatan pada Lembaga Pemasyarakatan Anak Blitar, 12 Mei 2015.

23 Pasal 14 huruf (e) Undang-undang Nomor 12 Tahun 1995 tentang Pemasyarakatan. 
ijin untuk memberikan penghormatan terakhir pada keluarga yang meninggal dunia.

c) Anak Didik Pemasyarakatan (Anak Pidana) mengeluhkan ingin ditempatkan di tempat ketrampilan yang ada di dalam Lembaga Pemasyarakatan.

d) Anak Didik Pemasyarakatan (Anak Pidana) mengeluhkan kurangnya buku bacaan yang ada di dalam perpustakaan.

2. Analisis pelaksanaan pemenuhan hak menyampaikan keluhan berdasarkan prinsip-prinsip perlindungan anak dalam Undang-undang Nomor 11 Tahun 2012 tentang Sistem Peradilan Pidana Anak

Berdasarkan Konvensi Hak Anak, terdapat

4 (empat) prinsip perlindungan terhadap anak, yaitu Prinsip Non Diskriminasi, Prinsip Kepentingan Terbaik Bagi Anak (Best Interest of The Child), Prinsip Hak Hidup, Kelangsungan Hidup dan Perkembangan (Right to Life, Survival and Development), dan Prinsip Penghargaan terhadap Pendapat Anak (Respect for the views of the Child). ${ }^{24}$

SebagaisalahsatupenjabarandariKonvensi Hak Anak, pada Undang-undang Nomor 11 Tahun 2012 tentang Sistem Peradilan Pidana Anak terdapat prinsip-prinsip perlindungan terhadap anak, yaitu: prinsip perlindungan, prinsip keadilan, prinsip non diskriminasi, prinsip kepentingan terbaik bagi anak, prinsip penghargaan terhadap pendapat anak, prinsip kelangsungan hidup dan tumbuh kembang anak, prinsip pembinaan dan pembimbingan, prinsip proporsional, prinsip perampasan kemerdekaan sebagai upaya terakhir dan prinsip penghindaran pembalasan. ${ }^{25}$

Dalam melakukan analisa terkait dengan rumusan pokok permasalahan pertama penulis tidak menggunakan semua prinsip perlindungan anak yang terdapat dalam UU 11 Tahun 2012 tentang SPPA. Penulis hanya menggunakan prinsip-prinsip perlindungan anak dalam Undang-Undang SPPA yang berkaitan dengan proses pembinaan bagi Anak Yang Menjalani Pidana di Lembaga Pemasyarakatan utamanya dalam hal pelaksanaan pemenuhan hak menyampaikan keluhan, diantaranya: prinsip perlindungan, prinsip non diskriminasi, prinsip kepentingan terbaik bagi anak, prinsip kelangsungan hidup dan tumbuh kembang anak, prinsip pembinaan dan pembimbingan dan prinsip proporsional.

\section{a. Prinsip Perlindungan}

Anak Didik Pemasyarakatan (Anak Pidana) dalam menjalani pidana di dalam Lembaga Pemasyarakatan Anak Blitar wajib mendapatkan perlindungan. Berdasarkan Undang-Undang Nomor 11 Tahun 2012 tentang Sistem Peradilan Pidana Anak, yang dimaksud dengan perlindungan meliputi kegiatan yang bersifat langsung dan tidak

24 Hadi Supeno, Kriminalisasi Anak Tawaran Gagasan Radikal Peradilan Anak tanpa Pemidanaan, Gramedia Pustaka Utama, Jakarta, 2010, hlm. 53.

25 Pasal 2 Undang-undang Nomor 11 Tahun 2012 tentang Sistem Peradilan Pidana Anak. 
langsung dari tindakan yang membahayakan anak secara fisik dan/atau psikis. ${ }^{26}$

Salah satu bentuk perlindungan yang dilakukan oleh Lembaga Pemasyaraaktan Anak Blitar terhadap Anak Didik Pemasyarakatan (Anak Pidana) adalah Anak Didik Pemasyarakatan (Anak Pidana) berhak untuk menyampaikan keluhan terhadap perlakuan yang semenan-mena dari Petugas Pemasyarakatan maupun dari Anak Didik Pemasyarakatan (Anak Pidana) yang lainnya. ${ }^{27}$

Perlakuan yang layak kepada Anak Didik Pemasyarakatan (Anak Pidana) dari Petugas Pemasyarakatan pada Lembaga Pemasyarakatan Anak Blitar telah dilaksanakan dan sesuai dengan ketentuan dalam Pasal 64 ayat (2) huruf a Undang-Undang Nomor 23 Tahun 2002 tentang Perlindungan Anak sebagaimana telah diubah dengan UndangUndang Nomor 35 Tahun 2014 tentang Perubahan atas Undang-Undang Nomor 23 Tahun 2002 tentang Perlindungan Anak. Hal ini dapat diketahui dari wawancara yang dilakukan oleh peneliti dengan salah satu Anak pada Lembaga Pemasyarakatan Anak Blitar, bahwa dalam pelaksanaan pembinaan sudah tidak terjadi perlakuan yang semena-mena dari Petugas Pemasyarakatan kepada Anak Didik Pemasyarakatan.

\section{b. Prinsip non diskriminasi}

Pelaksanaan pembinaan terhadap Anak Didik Pemasyarakatan (Anak Pidana) pada Lembaga Pemasyarakatan Anak dilakukan berdasarkan prinsip non diskriminasi. Berdasarkan Pasal 2 huruf c Undang-Undang Nomor 11 Tahun 2012 tentang Sistem Peradilan Pidana Anak, yang dimaksud dengan non diskriminasi adalah tidak ada perlakuan yang berbeda didasarkan pada suku, agama, ras, golongan, jenis kelamin, etnik, budaya dan bahasa, status hukum anak, urutan kelahiran anak, serta kondisi fisik dan/ atau mental. ${ }^{28}$

Bentuk perlakuan yang sama terhadap Anak Didik Pemasyarakatan (Anak Pidana) pada Lembaga Pemasyarakatan Anak Blitar salah satunya adalah pemberian jaminan berhubungan dengan keluarga. Anak Didik Pemasyarakatan (Anak Pidana) dalam melaksanakan pembinaan memiliki hak untuk mendapat kunjungan dari keluarganya. ${ }^{29}$

Dalam hal Anak Didik Pemasyarakatan (Anak Pidana) di dalam Lembaga Pemasyarakatan Anak Blitar yang keluarganya berdomisili atau bertempat tinggal di luar kota dan jarang dikunjungi oleh keluarganya, anak tersebut dapat menyampaikan permasalahan tersebut kepada walinyanya.

26 Penjelasan Pasal 2 huruf a Undang-undang Nomor 11 Tahun 2012 tentang Sistem Peradilan Pidana Anak.

27 Pasal 26 ayat (1) Peraturan Pemerintah Nomor 32 Tahun 1999 tentang Syarat dan Tata Cara Pelaksanaan Hak Warga Binaan Pemasyarakatan.

28 Penjelasan Pasal 2 huruf c Undang-undang Nomor 11 Tahun 2012 tentang Sistem Peradilan Pidana Anak.

29 Pasal 30 ayat (1) Peraturan Pemerintah Nomor 32 Tahun 1999 tentang Syarat dan Tata Cara Pelaksanaan Hak Warga Binaan Pemasyarakatan. 
Berdasarkan penelitian yang dilakukan oleh peneliti, adanya tindak lanjut yang dilakukan oleh Wali Pemasyarakatan terhadap keluhan yang disampaikan oleh Anak Didik Pemasyarakatan (Anak Pidana) dan memprosesnya dalam sidang Tim Pengamat Pemasyarakatan, sehingga diperoleh hasil sesuai dengan keluhan yang disampaikan oleh Anak Didik Pemasyarakatan (Anak Pidana), telah menunjukan bahwa Lembaga Pemasyarakatan Anak Blitar telah memberikan perlindungan hukum dengan cara melaksanaan hak yang dimiliki oleh Anak Didik Pemasyarakatan (Anak Pidana) yaitu hak untuk dikunjungi oleh keluarganya. Hal tersebut sesuai dengan ketentuan dalam Pasal 2 ayat (1) dan ayat (2) Konvensi Hak Anak. ${ }^{30}$

\section{c. Prinsip kepentingan terbaik bagi anak}

Pengambilan keputusan oleh Kepala Lembaga Pemasyarakatan Anak terkait dengan keluhan yang disampaikan oleh Anak Didik Pemasyarakatan (Anak Pidana) dilakukan berdasar pada prinsip kepentingan terbaik bagi anak. Berdasarkan Pasal 2 huruf d UndangUndang Nomor 11 Tahun 2012 tentang Sistem
Peradilan Pidana Anak, yang dimaksud dengan kepentingan terbaik bagi anak adalah segala pengambilan keputusan harus selalu mempertimbangkan kelangsungan hidup dan tumbuh kembang anak. ${ }^{31}$

Anak Didik Pemasyarakatan (Anak Pidana) pada Lembaga Pemasyarakatan Anak Blitar sesuai dengan ketentuan peraturan perundang-undangan memiliki hak dalam melaksanakan aktifitasnya. Salah satu hak yang dimiliki oleh Anak Didik Pemasyarakatan (Anak Pidana) di Lembaga Pemasyarakatan adalah hak menyampaikan keluhan.

Anak Didik Pemasyarakatan (Anak Pidana) di dalam Lembaga Pemasyarakatan Anak Blitar yang memiliki keahlian ataupun ketrampilan (memotong rambut, menjahit) mengeluhkan ingin ditempatkan di tempat ketrampilan yang ada di dalam Lembaga Pemasyarakatan Anak Blitar. Dengan ditempatkannya anak tersebut di tempat ketrampilan yang ada di dalam Lembaga Pemasyarakatan, diharapkan anak tersebut dapat menyalurkan keahliannya ataupun ketrampilannya kepada lembaga.

Berdasarkan wawancara yang dilakukan oleh peneliti dengan Anak Didik

30 Ayat (1) "Setiap Narapidana dan Anak Didik Pemasyarakatan berhak menerima kunjungan dari keluarga, penasehat hukum atau orang tertentu lainnya"

31 Pasal 2, Konvensi Hak Anak.

Ayat (1) "Negara-negara pihak menghormati dan menjamin hak-hak yang ditetapkan dalam konvensi ini bagi setiap anak yang berada di wilayah hukum mereka tanpa diskriminasi dalam bentuk apapun, tanpa memandang ras, warna kulit, jenis kelamin, bahasa, agama, pandangan politik, asal usul kebangsaan, etnik, status kepemilikan, cacat atau tidak, kelahiran atau status lainnya baik dari si anak sendiri atau atau dari orang tua walinya yang sah"

Ayat (2) "Negara-negara pihak akan mengambil semua langkah yang perlu untuk menjamin agar anak dilindungi dari semua diskriminasi atau hukuman yang didasarkan pada status, kegiatan, pendapat yang dikemukakan atau keyakinan dari orang tua anak, walinya yang sah atau anggota keluarganya" 
Pemasyarakatan (Anak Pidana), Lembaga Pemasyarakatan Anak Blitar telah memberikan perlindungan hukum, yaitu mereka diberikan fasilitas pendukung terkait dengan keluhan, dimana Anak yang memiliki keahlian ditempatkan di tempat ketrampilan sesuai dengan keahliannya dan Anak yang memiliki kegemaran membaca buku disediakan perpustakaan sebagai sarana membaca Anak. Hal tersebut sesuai dengan ketentuan dalam Pasal 3 ayat (1) Konvensi Hak Anak. ${ }^{32}$

\section{d. Prinsip hak hidup, tumbuh dan berkembang}

Lembaga Pemasyarakatan Anak dalam melaksanakan pembinaan terhadap Anak Yang Menjalani Pidana harus berdasarkan pada prinsip hak hidup, tumbuh dan berkembang. Berdasarkan Pasal 2 huruf f Undang-Undang Nomor 11 Tahun 2012 tentang Sistem Peradilan Pidana Anak, yang dimaksud dengan hak hidup, tumbuh dan berkembang adalah hak asasi yang paling mendasar bagi anak yang dilindungi oleh negara, pemerintah, masyarakat dan orang tua. ${ }^{33}$

Sebagai perwujudan dari prinsip hak hidup, tumbuh dan berkembang, Anak Didik Pemasyarakatan (Anak Pidana) pada Lembaga Pemasyarakatan Anak Blitar diberikan asupan gizi yang cukup terhadap makanan bagi anak yang menjalani pidana. Anak yang menjalani pidana di dalam Lembaga Pemasyarakatan Anak Blitar mendapatkan jatah makanan sebanyak 3 (tiga) kali dalam sehari, yang diberikan pada pagi hari, siang hari dan sore hari. Disamping itu Anak Didik Pemasyarakatan (Anak Pidana) pada Lembaga Pemasyarakatan dapat menerima makanan dari luar Lembaga Pemasyarakatan setelah mendapat ijin dari pertugas Lembaga Pemasyarakatan. Pemberian makanan dari luar biasanya dilakukan pada saat kunjungan dari keluarga anak tersebut. ${ }^{34}$

\section{e. Prinsip pembinaan dan pembimbingan}

Kegiatan bagi Anak Didik Pemasyarakatan (Anak Pidana) pada Lembaga Pemasyarakatan Anak dilaksanakan berdasarkan prinsip pembinaan dan pembimbingan. Berdasarkan Pasal 2 huruf g Undang-Undang Nomor 11 Tahun 2012 tentang Sistem Peradilan Pidana Anak, yang dimaksud dengan pembinaan dan pembimbingan adalah kegiatan untuk meningkatkan kwalitas ketakwaan kepada Tuhan Yang Maha Esa. ${ }^{35}$

Pada Lembaga Pemasyarakatan Anak Blitar sebagai bagian dari program pembinaan

32 Penjelasan Pasal 2 huruf d Undang-undang Nomor 11 Tahun 2012 tentang Sistem Peradilan Pidana Anak.

33 Pasal 3, Konvensi Hak Anak.

Ayat (1) "Dalam semua tindakan yang menyangkut anak yang dilakukan lembaga-lembaga kesejahteraan sosial pemerintah maupun swasta, lembaga peradilan, lembaga pemerintah atau badan legislatif, maka kepentingan yang terbaik bagi anak harus menjadi pertimbangan utama"

Penjelasan Pasal 2 huruf f Undang-undang Nomor 11 Tahun 2012 tentang Sistem Peradilan Pidana Anak.

34 Wawancara dengan Udin, penghuni wisma melati pada Lembaga Pemasyarakatan Anak Blitar, 16 Mei 2015.

35 Penjelasan Pasal 2 huruf g Undang-undang Nomor 11 Tahun 2012 tentang Sistem Peradilan Pidana Anak. 
terhadap Anak Didik Pemasyarakatan (Anak Pidana), setiap pagi setelah jadwal makan pagi dilakukan penyuluhan agama (semua Anak Didik Pemasyarakatan beragama Islam). Lembaga Pemasyarakatan Anak Blitar dalam hal penyuluhan agama islam telah bekerja sama dengan Kementerian Agama setempat. Sebagaimana ketentuan dalam Pasal 2 ayat (1) PP No. 32/1999 tentang Syarat dan Tata Cara Pelaksanaan Hak Warga Binaan Pemasyarakatan "Setiap Narapidana dan Anak Didik Pemasyarakatan berhak untuk melakukan ibadah sesuai dengan agama dan kepercayaannya”. Sebagaimana pelaksanaan pasal tersebut Lembaga Pemasyarakatan Anak Blitar juga memberikan kesempatan kepada anak yang menjalani pidana untuk melakukan sholat jum'at berjamaah pada masjid yang berada di dalam Lembaga Pemasyarakatan Anak Blitar.

\section{f. Prinsip proporsional}

Lembaga Pemasyarakatan Anak merupakan tempat menampung, membina dan merehabilitasi anak yang menjalani hukuman pidana. Penempatan anak pada Lembaga Pemasyarakatan Anak berdasarkan pada prinsip proporsional. Berdasarkan Pasal 2 huruf h Undang-Undang Nomor 11 Tahun 2012 tentang Sistem Peradilan Pidana Anak, yang dimaksud dengan proporsional adalah segala perlakuan terhadap anak harus memperhatikan batas keperluan, umur dan kondisi anak. ${ }^{36}$
Sejalan dengan diberlakukannya UU No. 11/2012 tentang SPPA, Anak Yang Menjalani Pidana ditempatkan pada Lembaga Pembinan Khusus Anak, sebagaimana pasal Pasal 85 ayat (1) "Anak yang dijatuhi pidana penjara ditempatkan di LPKA" dan Pasal 1 angka 20 "Lembaga Pembinaan Khusus Anak yang selanjutnya disingkat LPKA adalah lembaga atau tempat anak menjalani masa pidananya”. Begitupula ketentuan dalam Pasal 86 ayat (1) "Anak yang belum selesai menjalani pidana di LPKA dan telah mencapai umur 18 (delapan belas) tahun dipindahkan ke lembaga pemasyarakatan pemuda". Namun hingga saat ini masih belum terdapat LPKA, LPAS dan Lembaga Pemasyarakatan Pemuda sehingga anak yang menjalani pidana, anak yang menjalani pidana dengan usia 18 - 21 dan anak yang menjalani proses persidangan masih ditempatkan di Lembaga Pemasyarakatan Anak.

C. Kendala dan Upaya yang Dihadapi oleh Lembaga Pemasyarakatan Anak Blitar dalam Pemenuhan Hak Menyampaikan Keluhan bagi Anak Didik Pemasyarakatan (Anak Pidana) di Lembaga Pemasyarakatan Anak Blitar

Dalam rangka pelaksanaan pemenuhan hak menyampaikan keluhan bagi Anak Didik Pemasyarakatan pada Lembaga Pemasyarakatan Anak Blitar terdapat beberapa kendala dan upaya baik secara internal maupun eksternal.

36 Penjelasan Pasal 2 huruf h Undang-undang Nomor 11 Tahun 2012 tentang Sistem Peradilan Pidana Anak. 


\section{Internal}

Anak Didik Pemasyarakatan (Anak Pidana) pada Lembaga Pemasyarakatan Anak Blitar seringkali tidak dapat menyampaikan keluhan yang dimilikinya kepada Wali Pemasyarakatannya secara total. ${ }^{37}$ Hal tersebut dilatarbelakangi karena keterbatasan Petugas Pemasyarakatan (Wali Pemasyarakatan) yang berlatar belakang pendidikan psikologi.

Pada teori bekerjanya hukum, salah satu hal yang mempengaruhi bekerjanya hukum adalah struktur hukum (aparat penegak hukum). Petugas Pemasyarakatan diwajibkan memiliki jiwa profesionalisme yang tinggi dalam melakukan pekerjaannya.

Berdasarkan data yang diperoleh peneliti dalam melakukan penelitian pada Lembaga Pemasyarakatan Anak Blitar, pada Lembaga Pemasyarakatan Anak Blitar Wali Pemasyarakatan yang memiliki latar belakang pendidikan psikologi berjumlah 3 (tiga) orang dari total 23 (dua puluh tiga) jumlah Wali Pemasyarakatan yang ada. Dengan terbatasnya Wali Pemasyarakatan yang memiliki latar belakang pendidikan psikologi akan berakibat fungsi seorang Wali Pemasyarakatan sebagai orang tua asuh dan tempat menampung keluhan tidak dapat berjalan dengan baik. Sehingga dapat diketahui sistem yang terdapat pada Lembaga Pemasyarakatan Anak Blitar belum bekerja dengan baik karena struktur hukum yang terdapat pada Lembaga Pemasyarakatan Anak
Blitar (Wali Pemasyarakatan) tidak dapat berfungsi dengan baik karena keterbatasan pendidikan yang dimiliki oleh seorang Wali Pemasyarakatan.

\section{Eksternal}

Pada Lembaga Pemasyarakatan Anak Blitar seringkali ditemukan keluhan yang disampaikan oleh Anak Didik Pemasyarakatan (Anak Pidana) kepada Wali Pemasyarakatannya belum tentu benar adanya. Anak Didik Pemasyarakatan (Anak Pidana) seringkali mengelabuhi walinya dengan cara menyampaikan keluhan yang tidak sesuai dengan kondisi nyata yang ada pada dirinya kepada Wali Pemasyarakatannya. Biasanya Anak Didik Pemasyarakatan menyampaikan keluhan kepada walinya untuk ditempatkan di tempat yang mereka rasa enak dan menghindarkan mereka dari rutinitas pembinaan yang ada di dalam Lembaga Pemasyarakatan. Disamping itu Anak Didik Pemasyarakatan (Anak Pidana) takut untuk menyampaikan keluhan kepada Wali Pemasyarakatannya karena mendapatkan ancaman dari Anak Didik Pemasyarakatan yang lain. Hal ini dilatarbelakanggi karena Anak Didik Pemasyarakatan (Anak Pidana) yang lain akan iri/cemburu apabila teman satu kamarnya mendapatkan perlakuan atau tempat yang enak dalam Lembaga Pemasyarakatan.

Terkait dengan permasalahan tersebut dibutuhkan keberadaan Sidang Tim Pengamat Pemasyarakatan. Dalam sidang ini akan

37 Wawancara dengan Andika, penghuni Wisma Anggrek pada Lembaga Pemasyarakatan Anak Blitar, 9 Mei 2015. 
didapat laporan pemantauan dan penelitian oleh masing-masing seksi terhadap anak tersebut yang digunakan sebagai dasar atau bahan pertimbangan masing-masing seksi dalam pelaksanaan sidang Tim Pengamat Pemasyarakatan.

Dengan adanya sidang Tim Pengamat Pemasyarakatan diharapkan Keputusan yang telah diambil oleh Kepala Lembaga Pemasyarakatan berdasarkan masukan atau rekomendasi dari keputusan sidang Tim Pengamat Pemasyarakatan tepat sasaran dan memiliki manfaat bagi anak tersebut dalam rangka pelaksanaan pembinaan di dalam Lembaga Pemasyarakatan Anak Blitar.

Terkait dengan ketakutan Anak Didik Pemasyarakatan (Anak Pidana) untuk menyampaikan keluhan karena mendapat ancaman dari Anak Didik Pemasyarakatan yang lain, berdasarkan wawancara dengan salah satu Wali Pemasyarakatan pada Lembaga Pemasyarakatan Anak Blitar, hendaknya seorang Wali Pemasyarakatan harus memberikan perlindungan dengan cara merahasiakan keluhan yang disampaikan oleh anak didiknya kepada dirinya. Dengan merahasiakan keluhan yang disampaikan oleh anak didiknya diharapkan dapat mencegah terjadinya kecemburuan oleh anak didik yang lain yang terdapat dalam (1) satu kamar tahanan tersebut dan menghindarkan adanya bentrok fisik antara anak dalam 1 (satu) kamar tahanan.
Dengan adanya jaminan kerahasiaan dari seorang Wali Pemasyarakatan terhadap keluhan yang disampaikan oleh anak didiknya sehingga Anak Didik Pemasyarakatan tidak was-was atau kawatir lagi untuk menyampaikan keluhannya kepada Wali Pemasyarakatannya dan hal tersebut dapat menghindarkan adanya konflik yang terjadi antara anak didik.

\section{Simpulan}

Dari hasil pembahasan penulisan tesis ini, maka penulis dapat mengambil kesimpulan sebagai berikut:

1. Pelaksanaan pemenuhan hak menyampaikan keluhan bagi Anak Didik Pemasyarakatan (Anak Pidana) di Lembaga Pemasyarakatan Anak Blitar telah mencerminkan prinsip perlindungan anak.

2. Dalam pelaksanaan pemenuhan hak menyampaikan keluhan bagi Anak Didik Pemasyarakatan (Anak Pidana) di Lembaga Pemasyarakatan Anak Blitar terdapat beberapa kendala dan upaya yang berasal dari aspek internal maupun eksternal.

a. Internal.

- Kendala:

Keterbatasan Petugas Pemasyarakatan yang ditunjuk menjadi Wali Pemasyarakatan yang berlatar belakang pendidikan psikologi. 
- Upaya mengatasi kendala:

Mengadakan pelatihan teknis pendidikan psikologi bagi Petugas Pemasyarakatan yang ditunjuk sebagai Wali Pemasyarakatan.

b. Eksternal.

- Kendala:

Anak Didik Pemasyarakatan (Anak Pidana) takut untuk menyampaikan keluhan karena mendapat ancaman dari Anak Didik Pemasyarakatan (Anak Pidana) yang lain.

- Upaya mengatasi kendala: Wali Pemasyarakatan haruslah merahasiakan keluhan yang disampaikan oleh Anak Didik Pemasyarakatan (Anak Pidana) dari Anak Didik Pemasyarakatan (Anak Pidana).

- Kendala:

Semua keluhan yang disampaikan oleh Anak Didik Pemasyarakatan (Anak Pidana) kepada Wali Pemasyarakatannya belum tentu benar.

- Upaya mengatasi kendala:

Pengecekan Keluhan yang disampaikan oleh Anak Didik Pemasyarakatan (Anak Pidana) melalui Sidang Tim Pengamat Pemasyarakatan.

\section{DAFTAR PUSTAKA}

\section{Buku}

Barda Nawawi Arief, 1998, Beberapa Aspek Kebijaksanaan Penegakan dan Pengembangan Hukum Pidana, Citra Aditya Bakti, Bandung.

Budi Winarno, 2008, Globalisasi Peluang atau Ancaman bagi Indonesia, Erlangga, Jakarta.

Darwan, 2003, Hukum Anak Indonesia, Citra Aditya Bakti, Bandung.

Hadi Supeno, 2010, Kriminalisasi Anak Tawaran Gagasan Radikal Peradilan Anak tanpa Pemidanaan, Gramedia Pustaka Utama, Jakarta.
Lilik Mulyadi, SH MH, 2005, Pengadilan Anak di Indonesia, Teori, Praktik dan Permasalahannya, Mandar Maju, Bandung.

Maidin Gultom, 2008, Perlindungan Hukum

Terhadap Anak dalam Sistem Peradilan Pidana Anak di Indonesia, Refika Aditama, Bandung.

Petrus Iwan Panjaitan dan Pandapotan Simorangkir, 1995, Lembaga Pemasyarakatan dalam Perspektif Peradilan Pidana, Pustaka Sinar Harapan, Jakarta. 
Philipus M. Hadjon, Perlindungan Hukum

Bagi Rakyat Indonesia, 1987, Bina Ilmu, Jakarta.

Priyatno, Dwidja, 2002, Pelaksanaan Pidana

Penjara di Indonesia, RefikaAditama, Bandung.

R. Soeroso, 2009, Pengantar Ilmu Hukum, Sinar Grafika, Jakarta.

Romli Atmasasmita, 1996, Sistem Peradilan

Pidana, Bina Cipta, Jakarta.

\section{Peraturan Perundang-undangan}

Undang-undang Nomor 12 Tahun 1995 tentang Pemasyarakatan.

Undang-undang Nomor 23 Tahun 2002 tentang

Perlindungan Anak sebagaimana diubah dengan Undang-undang Nomor 35 Tahun 2014 tentang Perubahan atas UU No 23 Tahun 2002 tentang Perlindungan Anak.

Undang-undang Nomor 11 Tahun 2012 tentang Sistem Peradilan Pidana Anak.

Peraturan Pemerintah Nomor 32 tahun 1999 tentang Syarat dan Tata CaraPelaksanaan Hak Warga Binaan Pemasyarakatan.

\author{
Naskah Internet \\ Direktorat Jenderal Pemasyarakatan, Anak \\ yang berkonflik dengan Hukum, \\ http//dirjenpemasyarakatan.go.id.
}

